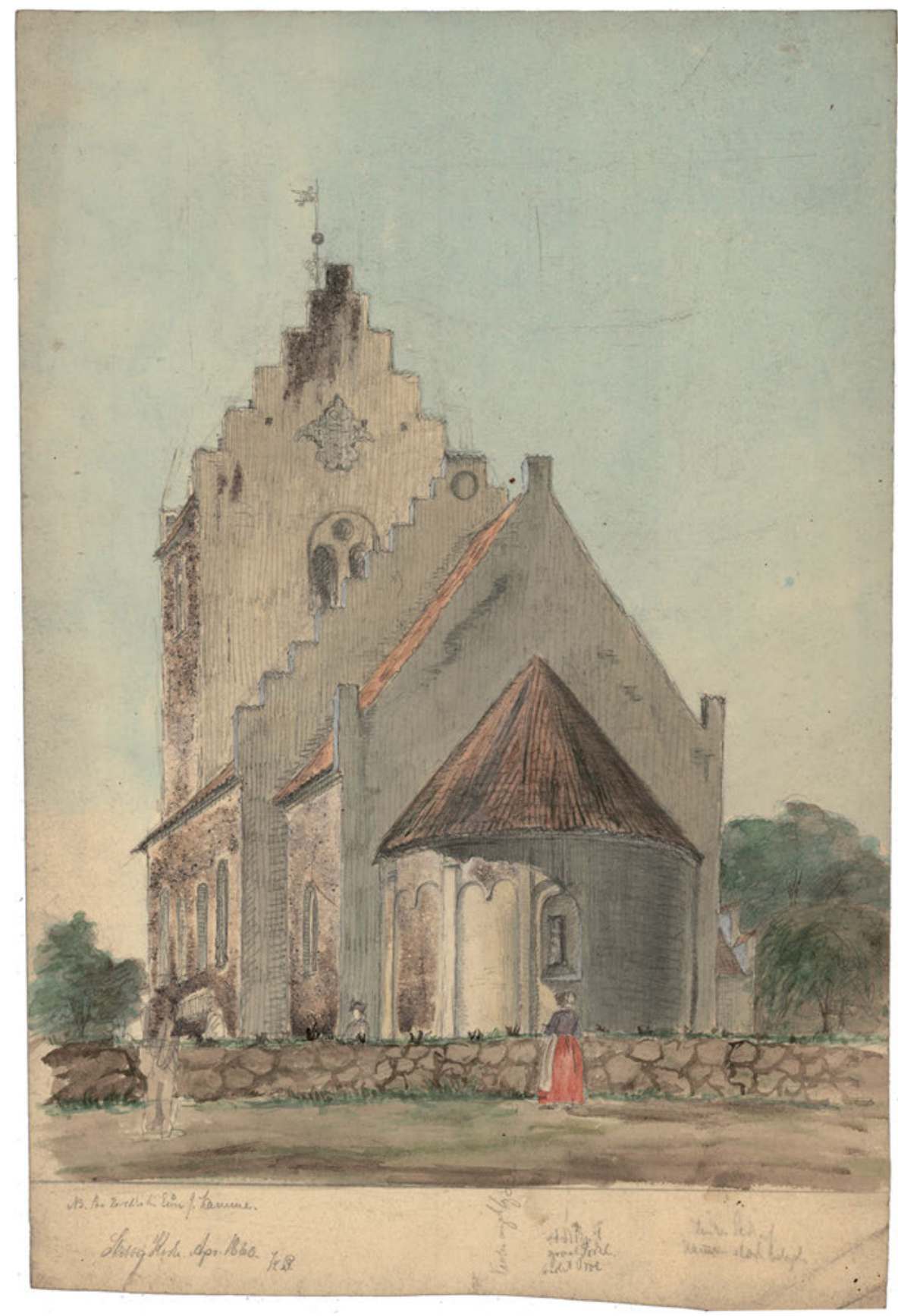

Fig. 13.1: Skibby Church, Zealand, Denmark. Exterior. H. B. Storck, 1860. Pencil and water colour, $17 \times 25 \mathrm{~cm}$. The National Museum of Denmark.

¿ Open Access. @ 2021 Line M. Bonde, published by De Gruyter. (@) BY-NC-ND This work is licensed under the Creative Commons Attribution-NonCommercial-NoDerivatives 4.0 International License.

https://doi.org/10.1515/9783110639476-014 
Line M. Bonde

Chapter 13

\section{Jerusalem Has Left the Building: The Church Inspection Act of 1861 as a Means to Rebuild Jerusalem in the Danish Parish Churches}

Jerusalem imagery vanished from the Danish churches in the nineteenth century. The faith was losing its grip on the increasingly secularized population and the church buildings became more and more dilapidated and desolate. Since the early Church, throughout the Middle Ages, and across the Reformation(s), it has been commonplace to understand the church building - God's house - as an allegory of the New Jerusalem. The visualization of Jerusalem in the church buildings was altered along with changing religious attitudes, but it was always represented, one way or the other. These explicit visualizations or allusions to Jerusalem ceased in the late eighteenth and first half of the nineteenth century. Yet, according to the Danish theologian N.F.S. Grundtvig's (1783-1872) sermon of 1810 "Wherefore is the Word of the Lord disappeared from out of His House?"1 the allegory itself, or at least the church building understood as God's house was still very much alive. This chapter explores how and what measures were taken in the last half of the century in an effort to "rebuild Jerusalem," as the state church was replaced by the so-called people's church.

\section{Paradigmatic Shifts and Dilapidated Parish Church Buildings}

In the first half of the nineteenth century, the ordinary Dane belonged to the Lutheran state church and was baptized, confirmed, and married in the local parish church, and interred in its churchyard. This was statutory. Revival movements, however, which

1 "Hvi er Herrens Ord forsvundet af hans Hus?" This was Grundtvig's dimissory sermon delivered in the Regency Church, Copenhagen, in order to be ordained. The Regency Church was a minor chapel primarily used for educational purposes by the Faculty of Theology. Translation from Martin Schwartz Lausten, Danmarks kirkehistorie (Copenhagen: Gyldendal, 1987), 206.

Note: I am grateful to Dr. Martin Wangsgaard Jürgensen for generously sharing his forthcoming article with me and for inspiring conversations on the subject.

Line M. Bonde, PhD Candidate, MF Norwegian School of Theology, Religion and Society, Oslo, Norway 
had risen during the previous century, still had a solid grip in parts of the population. Furthermore, the theologian Nikolaj Frederik Severin Grundtvig scorned the rationalist teachers, and his opponent the theologian and philosopher Søren Kierkegaard (1813-1855) raged against the Hegelianism of the established clergy, and all were in turn given tit for tat by the state church. Moreover, an insisting secularism gained ground in the wake of the Enlightenment movement and a general discontent was smouldering in the population, effectively resulting in the adoption of the Danish Act of Constitution of 1849 following the abolition of absolutism the previous year. The state church was now officially declared a "people's church" [Folkekirke], and freedom of conscience was introduced along with freedom of assembly. ${ }^{2}$ This radical change in governance, however, did not mean that state and Church was now separated. On the contrary, it is clearly stated in $\S 4$ of the Constitution that: "the Evangelical Lutheran Church shall be the Established Church of Denmark, and as such shall be supported by the State."3 Among other things, state support meant that the people's church was still governed by the king and the parliament, and thus that services and official holidays were specified by law, as was instruction in Christianity in the schools. The Faculty of Theology at the University of Copenhagen was also under the auspice of the newly established Ministry of Ecclesiastical Affairs and Public Instruction. ${ }^{4}$ Despite the regulatory efforts, the ecclesiological strife of the first half of the century only intensified with the democratic values coming into force. Put bluntly, three main factions asserted themselves: the so-called "rationalists" (liberal), the Grundtvigians, ${ }^{5}$ and the Inner Mission. ${ }^{6}$ The "rationalist" current was primarily detected among the urban, intellectual, clerical elite, who held positions at the University and in the Ministry. The Grundtvigians' main claim of ecclesiastical freedom had rooted itself among the many throughout the country, whereas the Inner Mission which had originated as a lay revivalist movement - had established itself by the late

2 Martin Schwartz Lausten, A Church History of Denmark, trans. Frederick H. Cryer (London: Routledge, 2016), 229ff. In paragraph 67 it says "Citizens shall be at liberty to form congregations for the worship of God in a manner according with their convictions, provided that nothing contrary to good morals or public order shall be taught or done," translation from International Labour Organization, "The Constitutional Act of Denmark," accessed January 15, 2019, https:/www.ilo.org/wcmsp5/groups/public/ -ed_protect/-protrav/-ilo_aids/documents/legaldocument/wcms_127469.pdf.

3 "Den evangelisk-lutherske Kirke er den danske Folkekirke og understøttes som saadan af Staten." This is still the situation today. Translation from International Labour Organization, "The Constitutional Act of Denmark."

4 Lausten, A Church History of Denmark, 230f.

5 A lot has been published on Grundtvig and his followers, and on the internal strife within the movement itself. Of newer literature on the subject see e.g. J. A. Hall, O. Korsgaard and O. K. Pedersen, eds., Building on the Nation: N.F.S. Grundtvig and Danish National Identity (Montréal, Québec: McGill-Queen's University Press, 2015), 27.

6 See Lausten, A Church History of Denmark, 238ff. See also Chapter 11 (Joar Haga), 214-23. 
1850s as "a movement of believers seeking to awaken the unbelievers" from inside the established people's church. All in all, the scepticism toward the established clergy loomed large. In an effort to meet especially Grundtvigian demands, additional laws were passed throughout the last half of the nineteenth century, resulting among other things in the establishment of so-called "free churches" and "elective congregations"; i.e. churches independent of the nation state. In other words, by the middle of the century the societal and political situation had drastically changed: Absolutism was replaced by constitutional monarchy and the state-controlled religion was replaced by the freedom of conscience.

Still, the vast majority of the general public were now members of the people's church, and their worship services were still held in the same old parish churches as they had been since the buildings themselves were erected during the long twelfth century. ${ }^{7}$ By the middle of the nineteenth century, however, many of the old parish churches were in a dilapidated state, marked by the ravages of time. Especially the church interiors had become crowded and variegated throughout the centuries, as generations of local gentry and ordinary parishioners had built large funerary monuments and galleries, hung epitaphs, donated different embellishments and objects etc., while older furnishings or even the church building itself had not necessarily been maintained or restored (Figs. 13.1, 13.2). ${ }^{8}$

Just how poor a state some of these church buildings were in at the time can be conveniently illustrated by an entry from June 14, 1817, in the church inspection protocol from Lunde District, Funen:

The porch of Hjadstrup Church needs a window. The entire church is "green" from moist, as the soil rises high up against the exterior Southern wall, and the church needs liming. The kneeler needs new upholstering, the book stool needs new fabric, and the female pews need backs. The closet for storage of building materials in the west end of the nave might be covered at the bottom, but lime dust still flies about the church interior, causing great harm to the health of the parishioners. The floor at the western most part of the nave is broken and has a nasty drop just in front of the door, which may cause one to fall over. Some of the beams in the tower are rotten, the staircase lacks steps, and the spiral staircase is worn and way to shallow. Also, the gate in the graveyard fence is broken. ${ }^{9}$

7 The vast majority of the stone churches in Denmark were built within the period 1080-1250. See Chapter 15 (Line M. Bonde), vol. 1, 299-323. After the Reformation, almost no new buildings were erected. Rather, the already standing buildings were refurbished. See also Jakob Kieffer-Olsen, Kirke og kirkestruktur i middelalderens Danmark (Odense: Synddansk Universitetsforlag, 2018), 4; Martin Wangsgaard Jürgensen, Ritual and Art across the Danish Reformation: Changing Interiors of Village Churches, 1450-1600, Ritus et Artes (Ritus 6) (Turnhout: Brepols, 2018), 3; Ulla Kjær and Grinder-Hansen, Kirkerne i Danmark, 2 vols. (Viborg: Boghandlerforlaget A/S, 1988), 5.

8 See for example Skibby Church, Zealand and Endelave Church, Jutland in Danmarks kirker (Copenhagen: Nationalmuseet, 1933-), from now on abbreviated DK[county]. DKFrbg: 2641-2703; DKAarhus: 5299-5336.

9 “Hjadstrup Kirkes våbenhus kunne trænge til et vindue. Hele kirken er 'grøn' af fugtighed, da jorden udvendigt ligger højt op mod søndre sides mur, og kirken trænger til kalkning. Knæfaldet 


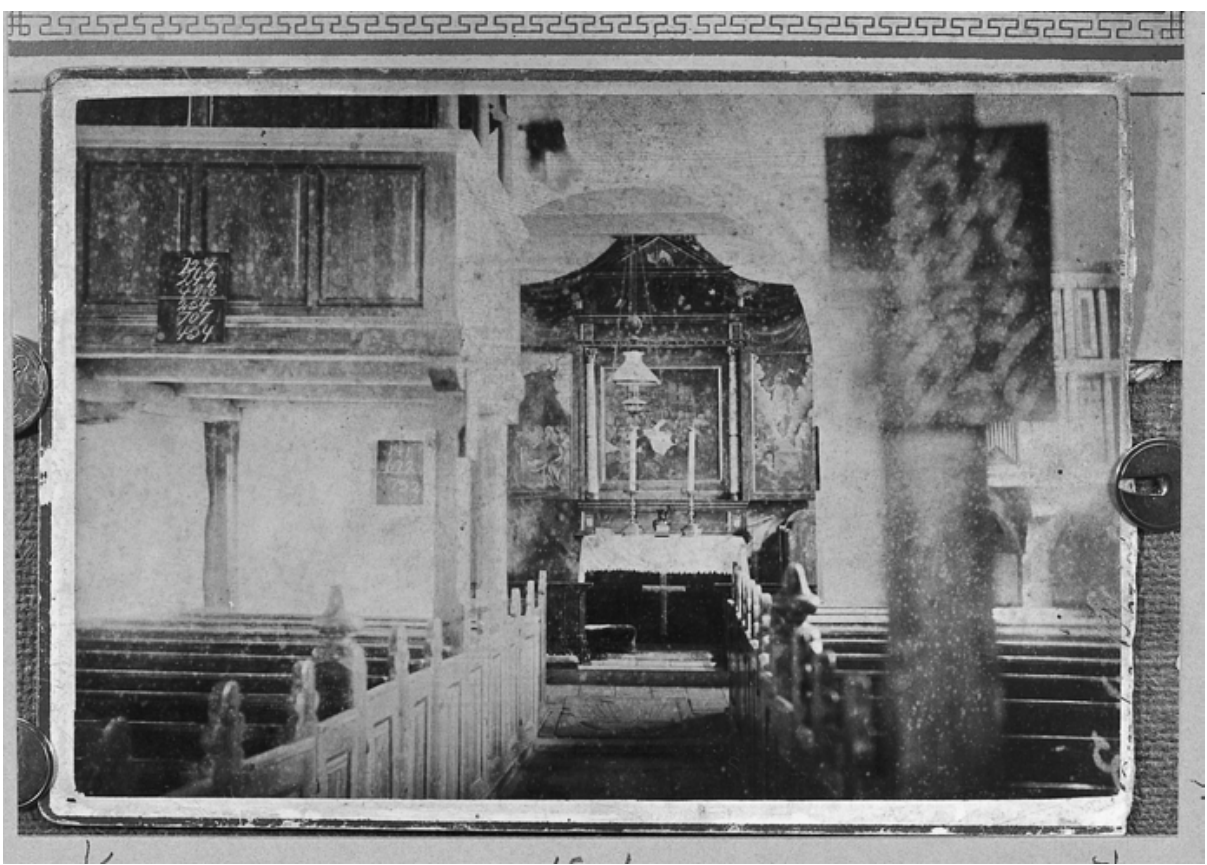

Fig. 13.2: Endelave Church, Jutland, Denmark. Interior facing East. Before 1890. The National Museum of Denmark.

It should be noted, though, that dilapidated parish churches were not specific to the nineteenth century. Almost all of the church buildings were privately owned and had been so at least since the Reformation. ${ }^{10}$ This meant that the less the church owners spent on maintenance, the more they would prosper from the tithes. Thus, pleas to the King for financial help with the up-keep are common already from the sixteenth century. In an effort to amend the problem, a yearly church inspection was enforced by law in $1643 .{ }^{11}$ The inspections were undertaken by the parish priest and four local members of the congregation; none of whom necessarily knew anything about buildings or furnishings. The lack of expertise resulted in many places in neglect or bungling reparations. For instance, in the parish church of Mesinge, Funen, a brick-built family vault collapsed twice during

trænger til udstopning og læsestolen til betræk og fruentimmerstolene til rygstød. Materialhuset nederst i kirken er godt nok afklædt forneden, men kalkstøvet flyver rundt i kirkerummet til skade for de kirkesøgendes sundhed. Nederst i kirken er gulvet ujævnt og har et slemt stød lige for døren, hvor man kan falde. I tårnet er nogle bjælker rådne, trappen mangler trin, vindeltrappen slidt og alt for lav. Endelig er kirkeporten noget beskadiget.” Landsarkivet Fyn, LAfyn, Stamhuset Østrupgård (Lunde Herred) Dokumenter vedr. Østrup og Hjadstrup Kirker, 1817. My translation.

10 Kjær and Grinder-Hansen, Kirkerne i Danmark, ch. 2.

11 For an account of the economic aspects of the churches see e.g. Kjær and Grinder-Hansen, Kirkerne i Danmark, ch. 2. 
the same service in 1823, even though it was reported already in 1812 that the ceiling of the vault was in such a poor condition that communicants risked bursting through down into the vault. ${ }^{12}$ And in Solrød Church on Zealand the pulpit was in 1814 described as being decrepit, and still fifty years later it was noted to be downright hazardous to climb it. $^{13}$ Not before 1802 was an ordinance passed, which stipulated that every inspection party had to include two building experts; a carpenter and a mason. Yet, as the two examples show, it all still came down to whether or not the patron was willing to finance the repairs needed. ${ }^{14}$ It was thus not until the so-called Church Inspection Act was introduced in 1861 that the church owners were lawfully obliged to keep their church buildings in good repair. More important for the purposes of this chapter, however, it should be noticed that the Act of 1861 differs radically from the previous legislation, "The Danish Law of King Christian V" [Danske Lov] in a number of ways. ${ }^{15}$ The Act of 1861 reflects not only a concern for the church buildings as cultural-historical objects, which is something entirely new; it also indicates a willingness of the nation state to mediate in the internal ecclesiological strife of the people’s church. We see this most clearly in §3, which explicitly states that it is the duty of the "Inspection of the Church" to take care that no shortcomings of the church building or its fittings may harm the worship service. ${ }^{16}$ As such, one of the primary concerns of the Act, it could be claimed, was to accommodate and provide a proper and decent space for worship, which could be accepted across the different ecclesiological fractions. As a means to practically obtain a proper space for uninterrupted worship, the Church Inspection Act operates with the concept "original style." That is, it clearly specifies that the "cleaning up" or repairing of a given church should be done in accordance with "its original style."17

At this point, one might wonder what all of this has got to do with visual allusions of Jerusalem. As stated in the brief introduction to this chapter, explicit Jerusalem imagery seems to have left the church buildings during the nineteenth century, despite the fact that Jerusalem allegory was still very much alive. To my mind, the two central aspects of the just mentioned $\S 3$ - namely the guarantee of an uninterrupted worship service and the specific mention of "original style" - are keys if we want to understand why Jerusalem left the building and how efforts were made to "rebuild it." Thus, these two interrelated phenomena will form the basis of the following discussions.

\footnotetext{
12 "kommunikanterne var 'i fare for at styrte ned i kælderbegravelsen.” DKOdense: 4651.

13 DKKbh: 1090.

14 Kjær and Grinder-Hansen, Kirkerne i Danmark, II, 16.

15 Specifically, on the church inspection: Kong Christian den Femtes danske lov af 15. april 1683, edited by V.A. Secher and S. Iuul (Copenhagen: Gad, 1949), 2. afd. ch. 22.

16 "Kirkesynet skal fornemmelig vaage over, at Gudstjenesten ikke lider ved Mangler i Kirkens Tilstand, eller i det Tilbehør, som til Gudstjenesten er nødvendigt . . . Enhver Kirke skal, saavidt andre Hensyn tilstede det, vedligeholdes saavel indvendig som udvendig paa den Maade, der stemmer overens med dens oprindelige Stiil.” Lov om nogle Bestemmelser vedrørende Kirkesyn, Præstegaardssyn m.v. Christiansborg Slot, den 19de Februar 1861 (Copenhagen: J.H. Schulz, 1861), 4-5, §3.

17 Lov om nogle Bestemmelser vedrørende Kirkesyn, 4-5, §3.
} 


\section{The Zeitgeist of the Danes and the Rise of a National Antiquarianism}

Jerusalem imagery was ubiquitous in a variety of art forms throughout the Middle Ages; not least in the architectural expression of the many church buildings understood as local Jerusalems. ${ }^{18}$ Following the official Danish Reformation of 1536, however, the medieval way of visualizing Jerusalem - often as architectural and/or floral paradisiac structures - seems to have rapidly declined. Instead, in the early-modern orthodox Lutheran church interiors, the metaphor of Solomon's temple was cultivated in the contemporary hymns, enabling church owners (jus patronatus) and local nobility to justifiably furnish the Lord's house with lavish, baroque interiors - just as Solomon had embellished his temple and as John had described the New Jerusalem in his Vision. ${ }^{19}$ In the many epitaphs of the seventeenth and first half of the eighteenth centuries, it became commonplace to have the towered and domed city of Jerusalem as a back drop to the Crucifixion. ${ }^{20}$ In an effort to secure admittance into the New Jerusalem, the deceased family were visually as well as symbolically inscribed directly into Salvation History. Yet, as already noted, in many places the churches and their crowded interiors decayed, and their miserable state soon became a metaphor for the declining religious sentiment in the population and thus for the Church as such.

The nineteenth-century linking of the physical and spiritual affective decline is illustrated quite tellingly in the poem "In a Village Church" [I en Landsbykirke] by the rural physician and poet Emil Aarestrup (1800-1856) published in 1837. I give here the full poem in verbatim translation, as the point is not so much its poetic qualities, but its keen analysis of contemporary attitudes to religion and the church:

\author{
We sat in the village church \\ A raw November sky \\ Lit lightly along the wall \\ The wall, green from moist. \\ Three, four old peasants \\ And a teacher and a clerk were the herd \\ Whom by the ratchet cry from the tower, \\ were called by the cracked bell.
}

\author{
Dust on all of the pews \\ Of paintings were only to be seen \\ The hand drawings in the chancel \\ By the skilled youth. \\ And, as depicted on Hogarth's plate (Fig. 13.3) ${ }^{21}$ \\ Engraved in bitter whim, \\ The poor box was \\ All covered by spider web.
}

18 See Chapter 1 (Kristin B. Aavitsland), vol. 1, 12-41; Chapter 15 (Line M. Bonde), vol. 1, 299-323; Chapter 19 (Martin Wangsgaard Jürgensen), vol. 1, 394-421.

19 See Chapter 17 (Martin Wangsgaard Jürgensen), vol. 2, 316-43; Chapter 19 (Joar Haga), vol. 2, 363-89; Chapter 20 (Beate Schmidt), vol. 2, 390-415.

20 Chapter 17 (Martin Wangsgaard Jürgensen), vol. 2, 316-43.

21 Refers to an engraving called "Married To An Old Maid," by the satirical British painter and engraver William Hogarth (1697-1764). In the bottom left is depicted a poor box covered in spider web. 
In place of an organ,

By winter gale's howling,

The door squeaked by its hinge

And the lead window chinked.

The only pair of angels,

That were to be found, lay in the gravel,

Worm-eaten, crippled,

Reclining in the porch.

And the candles on the altar

Where not lit - good gracious!

Nothing else could

More easily be spared.

The inch-long pieces

Sustained a profit in the candlestick,

And the altar cloth was a sordid

And cobbled old sheet.

There was a profound desolation, A coldness and a desertedness,

There was an awful emptiness,

As if in a grave among the dead.

There was - well, enough said!

You do not want know anymore,

And nor do I

Want to hint at the worst.

Enough, I guess, to dishearten

A virtuoso, let alone

A dilettante of the Faith

As I and my equals.

Albeit you - were at my side;

I noticed your youthful forehead

A cupola in the purest of styles,

Shaping a gracious arch.
It had no frown;

A heavenly unity

Were in these curves,

Were in these colours' purity.

And in your glances, lit

By the angels of youth and innocence,

Were altar candles that shone

Calmly and radiantly.

The silent language of the smile, In the shape and blush of the mouth, Surpassed the bliss and sweetness

Of all of the hymns.

Fully worthy an organ of silver

From the chairs in the gallery

A tuneful purl

Me from your silken gown

An oriental parable,

A delightful doctrine

Was in your soft

And brown-haired braiding.

And all the quiet devotion,

Which raises mind and heart,

And all the pious shiver,

Demanded by the shrine -

I sensed it in your closeness,

Your pensive, solemn

expression instigated on

My improvidence and my coldness. ${ }^{22}$

22 My translation. "Vi sad i Landsbykirken./ En raa Novemberhimmel/ Oplyste svagt langs Muren/ En fugtiggrønne Skimmel.//Tre, fire gamle Bønder,/ Samt Præst og Degn, var Flokken, Som med sit Skrat fra Taarnet,/ Høirevnet, kaldte Klokken.// Støv laae paa alle Bænke./ Af Malerier spored/ Man kun den flinke Ungdoms/ Haandtegninger i Choret.// Og, som paa Hogarths Plade/ I bittert Lune stukket,/ Var over Fattigbøssen/ Tæt Spindelvævet trukket.// Istedetfor et Orgel,/ Til Vinterstormens Tuden, Peb Døren med sit Hængsel/ Og klirrede Blyruden./ Det eneste Par Engle,/ Som fandtes, laae i Gruset,/ Ormstukne, invalide,/ Henslængt i Vaabenhuset.// Og Lysene paa Altret/ Var ikke tændt - bevares!/ Der gives intet Sted, hvor/ Meer ugeneert kan spares.// De tommelange Stumper/ Stod paa Profit i Stagen,/ Og Dugen var et smudsigt/ Og stoppet gammelt Lagen.// Der var en dyb Forladthed,/ En kulde og et Øde, / Der var en rædsom Tomhed,/ Som i en Grav hos Døde.// Der var - dog nok om dette!/ Du vil ei mere høre,/ Og jeg 


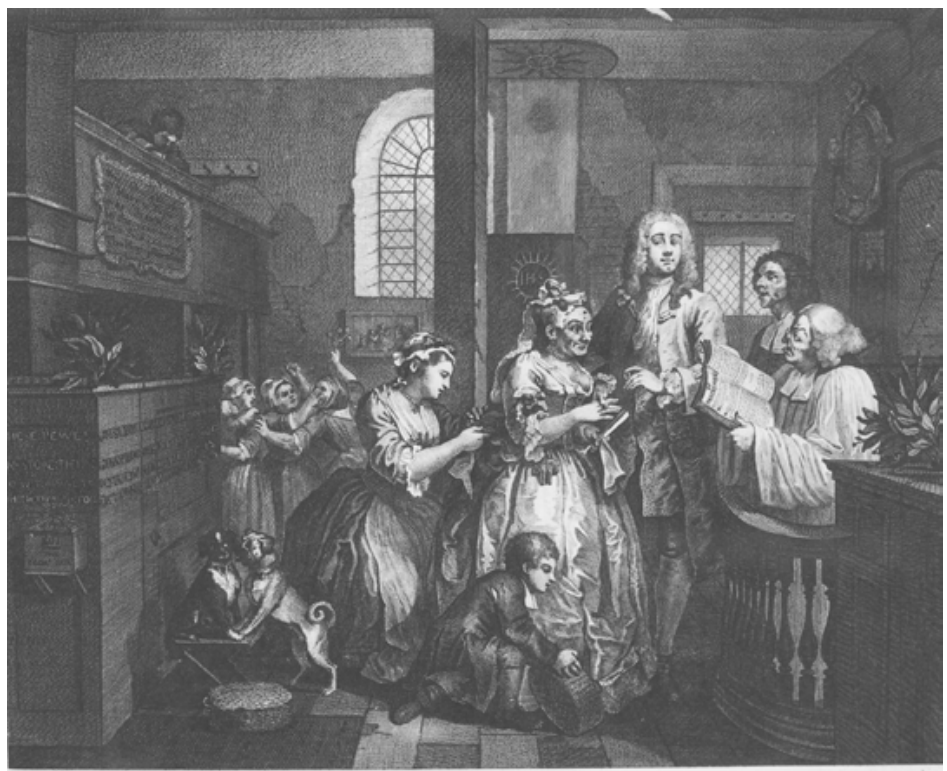

Fig. 13.3: "Married to an Old Maid" (plate 5) from A Rake’s Progress, 1735, by William Hogarth. Engraving.

The poem can, in its own right, be read in at least two ways: the very literal one, in which the church building and the faith has all but given way to worldly eroticism, or, it can be read metaphorically (also in a number of ways). Even though it can be discussed what a character such as Aarestrup wanted to convey in his poem, ${ }^{23}$ the very

vil ikke heller/ Det Værste just berøre.// Nok vel, til at forstemme/ En Virtuos, endsige/ En dilettant i Troen/ Som mig og mine Lige.// Men $d u$ - var ved min side;/ Jeg saae din unge Pande/ I renest Stiil en Kuppel,/ En yndig Hvælving danne.// Paa den var ingen Fure;/ Der var en himmelsk Eenhed/ I disse Liniers Bøining,/ I disse Farvers Reenhed.// Og dine Blik, som roligt/ Med klare Straaler brændte.// Det stumme Sprog i Smilet,/ I Mundens Form og Rødme,/ Overgik alle Psalmers/ Livsalighed og Sødme.// Fuldværd et Sølverorgel/ I Pulpiturets Stole/ Var en melodisk Rislen/ Mig af din Silkekjole./ En østerlandsk Parabel,/ En yndig Læresætning/ Var i de brune Lokker/ Og deres bløde Fletning.// Og al den stille Andagt,/ Som Sind og Hjerte hæver,/ Og al den fromme Gysen,/ Som Helligdommen kræver - // Fornam jeg i din Nærhed,/ Indgjød dit tankefulde/ Høitidelige Udtryk/ Mit Letsind og min Kulde.” Emil Aarestrup, "I en Landsbykirke," in Digte (Copenhagen: C.A. Reitzels Forlag, 1838), 9.

23 This is not the place to give an exhaustive analysis of the poem or to delve further into the "romanticist" works of Aarestrup in general. For discussions of Aarestrup and his poems, see e.g. Keld Zeruneith, Den frigjorte. Emil Aarestrup i digtning og samtid. En biografi (Copenhagen: Gyldendal, 1981), 11. It should be noticed that Georg Brandes wrote a biographical essay on Aarestrup, which was published in 1866 in Dansk Maanedsskrift, see Henning Fenger, Georg Brandes' læreår. Læsning, idéer, smag, kritik, 1847-1872 (Copenhagen: Gyldendal, 1955), 426, 444; and Claus Elholm Andersen, "Exile and Naturalism: Reading Georg Brandes Reading Emil Aarestrup," Scandinavian Studies 78, no. 4 (2006): 10. 
tangible description of the dilapidated state of a parish church building and its furnishings, and the lack of a vibrant congregation - even during service - reflects, at least to some extent, the reality in a number of parishes, as we clearly saw in the above cited protocol-entry from Hjadstrup Church. At any rate, Aarestrup's poem seems to epitomize the worst-case scenario voiced by the nineteenth-century theologians and teachers. Turning to the layered metaphorical reading, the dreary account of the actual building is counterbalanced by the warmth embedded in the description of the woman. The portrayal of the woman is in fact an affective echo of the emptiness of the dilapidated architecture. Her presence does indeed "instigate on the improvidence and coldness." As such, the woman becomes the Bride of Christ, the heavenly Jerusalem; an image of the ideal church building. That, which is not tangible is here described in a very tangible manner. Whether or not the woman was indeed intended as the Bride of Christ or as an actual human woman - an object erotized by the male gaze - does in this respect not matter. What matters is the desperate longing for a transcendent experience that so seems to characterize the nineteenth century. ${ }^{24}$

It is thus not surprising that we find Aarestrup's juxtaposition of "decay" and "longing" echoed in Grundtvig's hymn "The Church, it is an old house"25 [Kirken den er et gammel hus] from the same year as Aarestrup's poem. With the title constituting the first verse, the second verse instructively reads "Stands though its towers are falling." ${ }^{26}$ In essence, the hymn claims that the actual House of God is not the dilapidated church buildings or the established Church - no, the House of God is by now made up of the congregation only. ${ }^{27}$ As already mentioned, Grundtvig and his followers were very concerned with the declining religiosity in the population, for which they openly blamed the elitist, learned clergy. The scepticism towards the established Church and the theologically trained teachers was also shared by the Inner Mission movement. Yet, the Inner Mission wanted to rebuild the New Jerusalem from within the people's church; they wanted to awaken the living stones and thus re-congregate as the spiritual House of God. Moreover, even Jerusalem imagery was no longer introduced into

24 See Chapter 1 (Anna Bohlin and Ragnhild Johnsrud Zorgati), 12-50.

25 My verbatim translation. In the translation in use in English speaking countries by Norwegian Carl Døving (1867-1937) it is called "Built on the Rock the Church doth Stand." The full hymn in translation is published in Jens Christian Aaberg, Hymns and Hymnwriters of Denmark (Des Moines: The Committee on Publication of the Danish Evangelical Lutheran Church in America, 1945), 141; and in a modernized translation in Bert Polman, Marilyn Kay Stulken and James R. Sydnor, eds., Amazing Grace: Hymn Texts for Devotional Use (Louisville: Westminster John Knox Press, 1994), 174-5.

26 “står, omend tårnene falde." Translation from Aaberg, Hymns and Hymnwriters of Denmark, 141. 27 Stanza 3: "Vi er Guds hus og Kirke nu,/ bygget af levende stene,/som under kors med ærlig hu/ troen og dåben forene;/ var vi på jord ej mer end to,/ bygge dog ville han og bo/ hos os i hele sin vælde." // "We are God's house of living stones,/ Built for his own habitation;/ He fills our hearts, his humble thrones,/ Granting us life and salvation;/ Were two or three to seek his face, / He in their midst would show his grace, / Blessings upon them bestowing." Translation from Polman, Stulken and Sydnor, Amazing Grace, 174. 
the old buildings. As such, by the middle of the century it seems to have been widely held that the established Church and the physical church buildings had lost their ability to govern and preach the Word of God satisfactorily. And it is exactly the severity of these bitter reproaches - the spiritual and affective emptiness of the church space and the congregation, as described by Aarestrup - that is important to keep in mind if we want to grasp what was a stake during the nineteenth century and thus how these concerns were met in the new people's church and in the Church Inspection Act.

The primary and joint concern of the two just-mentioned ecclesiastical factions was, in fact, the fear that God was actually dead. That is, that Lutheranism had played its part and was becoming obsolete with industrialisation and its associated process of secularization - the death of God even became the metaphor for the secularisation process. ${ }^{28}$ This concern was also shared and already vehemently debated among the learned and established clergy of the state church and measures were taken to force people to attend service; albeit unsuccessfully. Yet, the concerns about the secularization did not vanish with the establishment of the people's church. If Jerusalem had left the church buildings, then there was no reason for the people to gather in congregation and attend the worship services of the people's church. The remaining believers might as well gather in the prayer houses [bedehuse] or in the buildings of the free churches, or even worse; they might not worship at all.

As already stated, the Church Inspection Act of 1861 is crucial to our understanding of how the newly established people's church responded to the concerns of secularism. We remember that it was explicitly stated that a church building should - as far as possible - be returned to its "original style." But just what are we to make of this notion of "original style"? What does it entail? The Act does not elaborate or qualify the notion, which obviously implies that it must have been common knowledge at this point. In a forthcoming article "The Properties of Style: Allusions to the Invisible in Nineteenth-Century Church Art and Architecture,"29 Martin Wangsgaard Jürgensen demonstrates how the layout and visual expression chosen for a new-built church of especially the second half of the nineteenth century was based on a contemporary theory of style. The specific conception of style was conditioned by a romantic nationalism, and inextricably linked to a notion of "ancestral authenticity" and nation building. The increasing interest in the by-gone hey-day ${ }^{30}$ of the Danes gave in turn

28 In the words of the Danish historian Jes Fabricius Møller, Jes Fabricius Møller, "Guds død - Et tema i det 19. århundrede," in Mentalitet og historie, eds., Charlotte Appel, Peter Henningsen and Nils Hybel (Ebeltoft: Skippershoved, 2002), 277.

29 Martin Wangsgaard Jürgensen, "The Properties of Style: Allusions to the Invisible in NineteenthCentury Church Art and Architecture," in In-Visibilis: Invisibility in Religion, Art and Ethics, eds. Anna Vind, Nanna Damgaard, Kirsten Busch Nielsen and Sven Rune Havsteen (Göttingen: Vandenhoeg \& Rupert, forthcoming), 15.

30 I.e, the pre-Reformation period, which was taken to be a part of Danish history full of great kings and a strong nation of proud and pious farmers. 
rise to a burgeoning medievalism and antiquarian awareness. Efforts were actively

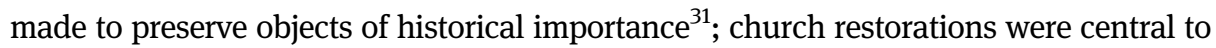
this, ${ }^{32}$ to which the Danish romanticist use of the word village church [landsbykirke] also testify. The zeal for restoring the old churches in accordance with their "original" style can partly be understood as a reaction to the primarily urban and elitist phenomenon of Neo-Classicism, taking Ancient Greek and Roman temples as templates. ${ }^{33}$ The example par excellence, of course, being the Church of Our Lady in Copenhagen (consecrated 1829) built by the most famous Danish architect of the early nineteenth century, C.F. Hansen (1756-1845) (Fig. 13.4). The Neo-Classical church buildings were harshly criticised and accused of being unsuitable for Christian worship: "One cannot in this day and age, either in the North or the South, worship God in Greek temples or live in Pompeian houses."34 Another, but no less important part of the growing interest in the layout and style of church buildings was the rapidly expanding railway network. Brand-new towns were established all the way along it and they all needed church buildings. ${ }^{35}$ Not since the massive stone church-buildings of the twelfth century had so many new churches been erected in Denmark at once. Most likely in consonance with the ongoing ecclesiastical strife, the main question then arose: what was in a church building? Or, in other words: What were the purposes of a church building and how could it be conveyed through its architecture and furnishings? That is, how could it be used as means to rebuild Jerusalem and prohibit the increasing secularism?

\section{Rebuilding Jerusalem for the Edification of the People}

Clearly, the Neo-classical forms and formats of the first half of the century were not the answer. It was necessary to look elsewhere. The very founder of Danish art history, Niels Laurits Høyen (1798-1870) and the architect Frits Uldall (1839-1921)

31 The burgeoning antiquarian interest resulted in the foundation of Oldnordisk Museum in 1819. 32 See, e.g., Rolf Graae, "De gamle Kirkers Restaurering," in Kirkebygning og teologi, eds., Johan Exner and Tage Christiansen (Copenhagen: G.E.C. Gads Forlag, 1965), 143.

33 Jürgensen, “The Properties of Style," 15. See also Hugo Johannsen and Claus M. Smidt, Kirkens huse, Danmarks arkitektur (Viborg: Gyldendalske Boghandel, Nordisk Forlag, 1981), $156 \mathrm{ff}$.

34 Translation from Jürgensen, "The Properties of Style," 15. For the original text, see Christian Molbech, Anmærkninger over Nyere Tiders Architektur særdeles i Danmark og I Kiøbenhavn, med nogle Ord om Fornyelsen af Gammel Bygningsstil i Sverige (Copenhagen: Kgl. Danske Videnskabernes Selskab 1855), 15. 35 Jürgensen, “The Properties of Style," 15; Jürgensen, Ritual and Art, 3; Vagn Riisager, "De nye kirker og traditionen," in Kirkebygning og teologi, eds. Johan Exner and Tage Christiansen (Copenhagen: G.E.C. Gads Forlag, 1965), $157 f$. 


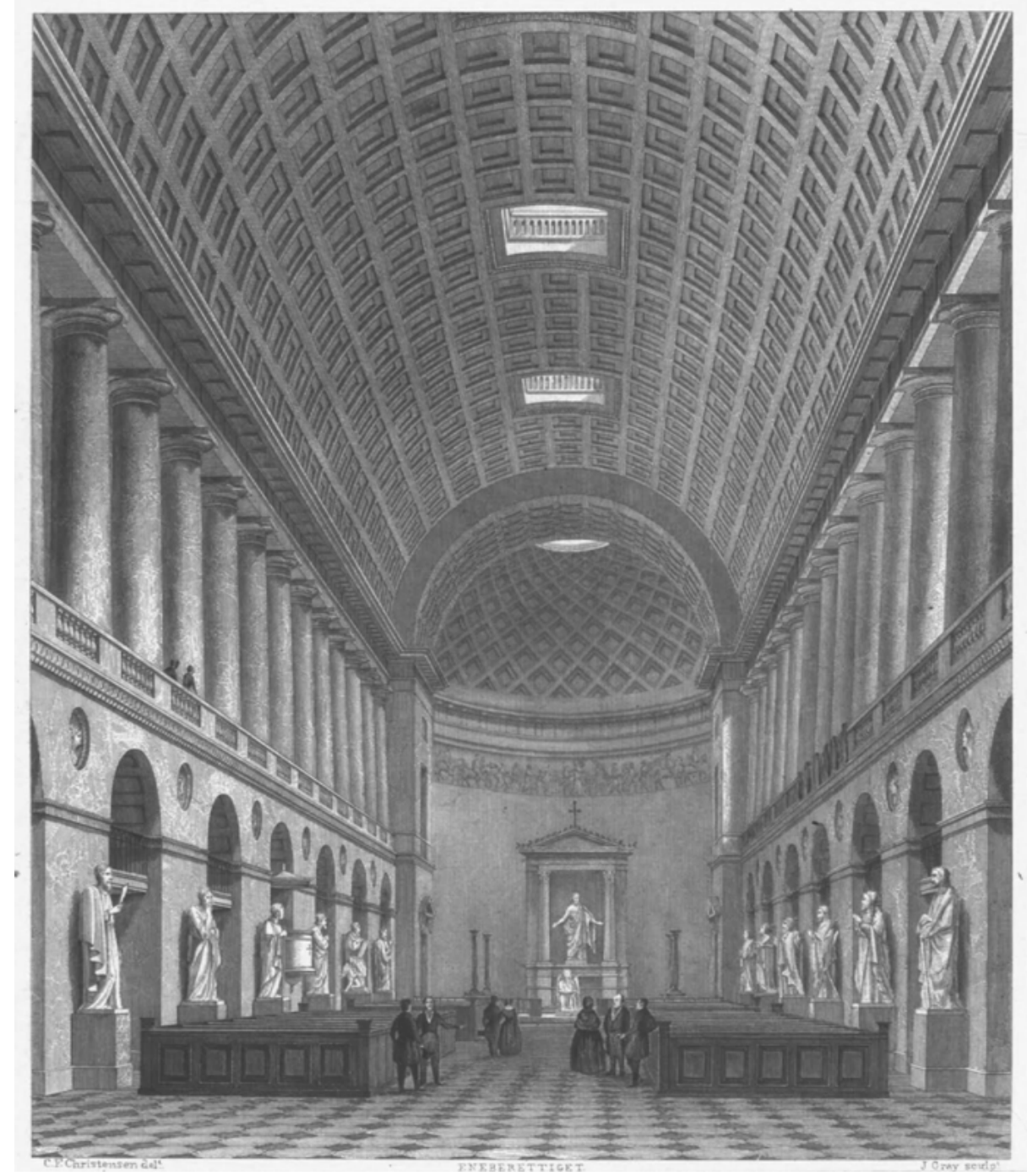

Fig. 13.4: Church of Our Lady, Copenhagen. Interior facing East, 1840-1849. Engraving. The Royal Library, Copenhagen.

were among the pioneers in facing these questions and the first to convert the theoretical debates into concrete stylistic principles, which - more importantly - seem to have been generally accepted by the population and not least the people's church. As many of their contemporaries, Høyen and Uldall believed that the primary purpose of the style was affective. The primary function of a church building and its furnishings' style was to generate a specific aesthetic "atmosphere," beneficial for the Protestant churchgoer to open his heart and take in the Word of God in proper 
worship. ${ }^{36}$ Even though neither Høyen or Uldall use the specific term "atmosphere," especially Høyen describes qualities embedded in specific architectural styles, which are contained by the German philosopher Gernot Böhme's phenomenological atmosphere theory. ${ }^{37}$ Overly simplified, this means that "atmosphere" is more than traditional (i.e. judgement based) aesthetics, it is also existential. As such, aesthetic "works" - in our case the church buildings and their "original style" - can be defined as production of atmospheres. Without going into Böhme's redefinition of classic ontology, what is essential here, is that the atmosphere of the "work" has the potential to generate affection, emotion, and imagination in the embodied perceiver. ${ }^{38}$

Keeping Böhme's conception of "atmosphere" in mind, let us return to the stylistic ideals of Høyen and Uldall. These were based on the notions of "tradition" and "authenticity.” Høyen, for instance, explicitly states in a lecture from 1853 that: "only in a vibrant Church that needs it, can church art sprout and thrive. Alas, the past of Lutheranism does not merit great expectations in this regard." ${ }^{39} \mathrm{He}$ is quite clearly hinting at the decline in the public religiosity and he blames the lack of "atmosphere" in orthodox Lutheran church art. The logical consequence of dismissing the previous centuries of art was to look to the pre-Reformation period; the Middle Ages. As already noted, this was also when almost all of the parish churches were built, as new builds of churches decreased already from the Late Middle Ages and almost came to a complete halt after the Reformation. ${ }^{40}$ Some scholars have subsequently claimed that the evocation of a medieval architectural language was inevitable as there were as good as no Renaissance or Baroque churches that could have set the fashion; the medieval churches were the only ones at hand and thus the only authentic ones. ${ }^{41}$ Such an interpretation is to my mind faulty, or at least too simplistic.

Looking beyond the boundaries of Denmark, national romantic currents were rapidly spreading and the local architectural remnants from the Middle Ages became a means to legitimate the nation state through the antiquity and grandness of ancestral heritage. ${ }^{42}$ Høyen was very much aware of the European intellectual debates associated

36 Niels Laurits Høyen, “Om Kirkelig Konst. Foredrag paa det kirkehistoriske Selskabs Møde 1853,” in Niels Laurits Høyens Skrifter II, ed. J. L. Ussing (Copenhagen: Thieles Bogtrykkeri, 1874), 21; Frits Uldall, “Om de Danske Landsbykirker og Deres Istandsættelse,” Ny Kirkehistoriske Samlinger IV (1867), 20.

37 This might seem somewhat contradictory, as Böhme himself dismisses past aesthetic theory. Gernot Böhme, “Atmosphere as the Fundamental Concept of a New Aesthetics,” Thesis Eleven 36 (1993): 15.

38 Gernot Böhme, Atmosphäre: Essays Zur Neuen Ästhetik (Frankfurt am Main: Suhrkamp, 1995$), 15$.

39 "Kirkelig Konst kan kun fremspire og trives i et kirkeligt Liv, som behøver den, og Lutheranismens Fortid er ikke i Stand til at vække synderlige Forventninger i saa Henseende.” My translation. Høyen, “Om Kirkelig Konst,” 22.

40 Jürgensen, Ritual and Art, 3; Kieffer-Olsen, Kirke og kirkestruktur, ch. 7.

41 See e.g. Riisager, “De nye Kirker og Traditionen,” 19.

42 Tina Waldeier Bizzarro, Romanesque Architectural Criticism: A Prehistory (Cambridge: Cambridge University Press, 1992), 23; and Marvin Trachtenberg, "Desedimenting Time: Gothic Column/ Paradigm Shifter,” RES: Anthropology and Aesthetics 40 (2001): 31. 
with the establishment of stylistic denominators, as they were in turn a large part of the development and establishment of academic humanistic disciplines, not least art history. An example of just how fundamental the debates were can be illustrated by the 1849book The Seven Lamps of Architecture by the English art critic John Ruskin: "It is as the centralisation and protectress of this sacred influence, that Architecture is to be regarded by us with most serious thought. We may live without her, and worship without her, but we cannot remember without her." ${ }^{43}$ Ruskin uses the allegory of "the seven lamps" to define what he takes to be God-given architectural principles applicable to both ecclesiastical and secular buildings across time periods. His overarching architectural theory is, in essence, an effort to repair the post-Kantian rift between religion and aesthetics, which he believed had caused the growing societal secularization. Moreover, what is implied in the Victorian quote is that architecture is visual rhetoric. Just like Ruskin, both Høyen and Uldall were concerned with the rapidly declining religiosity in the people. And just like Ruskin, they too believed that the only way to rouse the spirit of the populace through church art and architecture was to revive the style of a time in which religious imagery was solemn visual rhetoric, able to spur divine insights in the worshipper through the generations of "atmosphere." As such, an "authentic style of the ancestral Middle Ages" came to be the prevailing ideal. It was claimed that a specific religious "atmosphere" was embedded in the forms and formats of the Middle Ages; a quality the Lutheran art of the previous century did not have. Lutheran art was taken to be "empty," devoid of spirit, and completely lacking in ability to spur piety in the parishioner. Put into practice, this meant that an "authentic" or "original" style had to be identified and characterized, so that new churches could be built in accordance with their purpose and so that the old churches could have their original and affective style restored.

Stylistic debates had been going on in Europe and England since the late eighteenth and early nineteenth century. The elegant and limber shapes and formats of the so-called Gothic were taken to be Germanic in origin, while the so-called Romanesque - a term invented somewhat later than Gothic - was understood as coarse imitations of classical Roman architecture. ${ }^{44}$ These two styles of respectively the "round arch" (Romanesque) and the "pointed arch" (Gothic) were identified as the "original" styles of the Danish parish churches. At first, they were used interchangeably in the actual buildings, ${ }^{45}$ but they were soon developed into the modern stylistic concepts of "Romanesque" and "Gothic" though their origin as traditional or authentic Danish styles were never further discussed. ${ }^{46}$

43 John Ruskin, The Seven Lamps of Architecture (Sunnyside: G. Allen, 1889), 178. Ruskin wanted "medieval" parish church buildings all over England.

44 Bizzarro, Romanesque Architectural Criticism, 23.

45 For a description of a "typical" twelfth-century church building, see Chapter 15 (Line M. Bonde), vol. 1, 299-323. For changes to the buildings across the reformation see Jürgensen, Ritual and Art.

46 Moreover, reading through Høyen's published lectures and essays, he only actively employs the term "Romanesque" somewhat late in his oeuvre. J. L. Ussing ed., Niels Laurits Høyens Skrifter, vol. II. (Copenhagen: Den Gyldendalske Boghandel, 1874), 24. 
Whatever the case, to Høyen and his contemporaries, be they compatriots or European colleagues, tradition and style were inextricably connected. Because in the "original" forms and formats lay the powerful tradition of institutional Christianity. As such, by evoking the visual rhetoric of the Middle Ages, it was argued, the worshipper could be attuned and reached by the "atmospheres." As such, the "original" styles were understood as intermediaries between past and present, between spiritual anticipation and despair. With regards to the new-built churches along the railway-system in Neo-Gothic or Neo-Romanesque styles, Wangsgaard Jürgensen argues that these "churches reminded the congregation that they were part of the same community and Christian fellowship as had always existed." ${ }^{47}$ He goes on explicating that the church building was not merely supposed to be an aesthetic link, rather "the church building should now fulfil the role as the space for prayer and private meditation." ${ }^{48}$ What Wangsgaard Jürgensen is describing here is, essentially, the ecclesio-architectural theorists' response to Aarestrup's transcendental longing, which could only be met by generation of the right "atmospheres."

Yet, the question still remains as to how this longing was met in the many old parish church buildings, which had all been rebuilt during the centuries and which, by the middle of the nineteenth century, looked rather eclectic in stylistic terms. This is where we will once again turn to the Church Inspection Act of 1861, as the implications of the above cited $\S 3$ should by now be much clearer. The Act itself, which officially was written by the theologian and Minister of Ecclesiastical Affairs and Public Instruction, Ditlev Gothard Monrad (1811-1887), was in all likelihood conceived in collaboration with Høyen. This is clearly inferred in the request to restore the building in accordance with its "original style." Another, but no less prominent aspect of the stylistic ideals is the materiality of the architectural and decorative elements which are also emphasized in the Act. For instance, it is stipulated in $\S 8$ that the ceiling, pews, pulpit, altar frontal and other wooden furnishings should be "painted in a suitable oil colour, unless they are of oak or of other hardwood, then a varnish is sufficient." 49 It goes on saying that baptismal fonts, portals, or sculptures hewn in granite should not be covered in paint. ${ }^{50}$ The ideal was to accentuate the raw material. Yet, it was not the material in itself, which was important. Rather, it was the connotations of the materiality that mattered. This is why a "suitable oil colour" meant dark oaky brown. In other words, it was held that the imitation added to the combined affective quality of the church space, it generated "atmosphere."

47 Jürgensen, “The Properties of Style,” 15.

48 Jürgensen, “The Properties of Style,” 15.

49 "bør det altid males med en passende Oliefarve.” Lov om nogle Bestemmelser vedrørende Kirkesyn, (Copenhagen: J.H. Schulz, 1861), 9, §3. My translation.

50 In 1862 the churches were instructed to actively remove all remnants of paint from granite carvings. See e.g. Karin Kryger, “Middelalderens Bemalede stenskulptur i Danmark,” Hikuin 3 (1977): 300. 
To illustrate the impact of the Act, we could conveniently look to the parish of Uldum, Jutland, as an extreme example. In 1880 and 1881 the church inspection found that numerous repairs were needed; interior as well exterior. Quite a few of the defects noted by the inspection clearly reflect the stipulations of the Church Inspection Act. For instance, it is prescribed that windows should be deployed in the north wall of the nave, the lead roof needed to be replaced, and the porch should be completely rebuilt (Fig. 13.5). However, as the railway system was planned to reach the village of Uldum, and as its two neighbouring villages of Langskov and Grejs were building brand-new churches, it was decided that the old church should be replaced by a new building, as the old one was too small, dilapidated, and, as it is stated: "in architectural terms it is worthless." 51 The new church building was erected in the Neo-Gothic style, and as such displayed pointed arches in all the wall openings (Fig. 13.6). ${ }^{52}$ Moreover, the ceiling is constructed as a "Nordic" hall "in accordance with the national romantic and Grundtvigian beliefs of the congregation" (Fig. 13.7). ${ }^{53}$ In accordance with the stylistic ideals of Høyen, Uldall, and the Act, a large portion of the old church's fittings and furnishings were reused in the new church building; for instance the baptismal font of granite, the sculptural parts of the late medieval triptych (altarpiece), ${ }^{54}$ and the baroque pulpit. The colour suite was also in accordance with the trends of the day, such as keeping all woodwork in a dark brown oaky colour (Fig. 13.7).

Though Uldum is not an exceptional example (a number of medieval churches were in fact torn in this period), the vast majority of parish churches were not torn but instead often subjected to complete overhauls (ideally) according to the guidelines of the Act. In a small book on the changes of the church interiors from the Reformation and throughout the nineteenth century, the Danish art historian Marie-Louise Jørgensen gives a condensed overview of the major alterations; albeit focusing only on Zealand. ${ }^{55}$ Despite the explicit geographical delimitation, Jørgensen's walk-through of the changes can in fact be taken to reflect the general trends across the country - at least with regards to those pertaining to the nineteenth century. The primary difference between the eighteenth- and the later nineteenth-century interiors was the spatial organisation. And during the last half of the nineteenth century, the cluttered spaces were, roughly speaking, cleaned up. Added side chapels were in many churches closed off from the nave, and galleries were taken down. Confessionals and

51 “og ' $\mathrm{i}$ arkitektonisk henseende' havde den ikke 'ikke noget værd'," citing the inspection protocol; DKVejle: 2195.

52 DKVejle: 2195.

53 At least according to the vicar, Finn Esborg. Finn Esborg and Børge Haugstrup, Uldum Kirke 1883-2008 (Uldum: Udgivet af menghedsrådet, 2008), 13. This type of ceiling, however, is not commonplace in neither the Neo-Romanesque churches, nor the twelfth-century churches.

54 The rest of the altarpiece was placed on the attic in accordance with paragraph X.

55 Marie-Louise Jørgensen, Kirkerummets forvandling. Sjællandske Landsbykirker Indretning Fra Reformationen til slutningen af 1800-tallet (Copenhagen: Nationalmuseet, 2009), 26. 


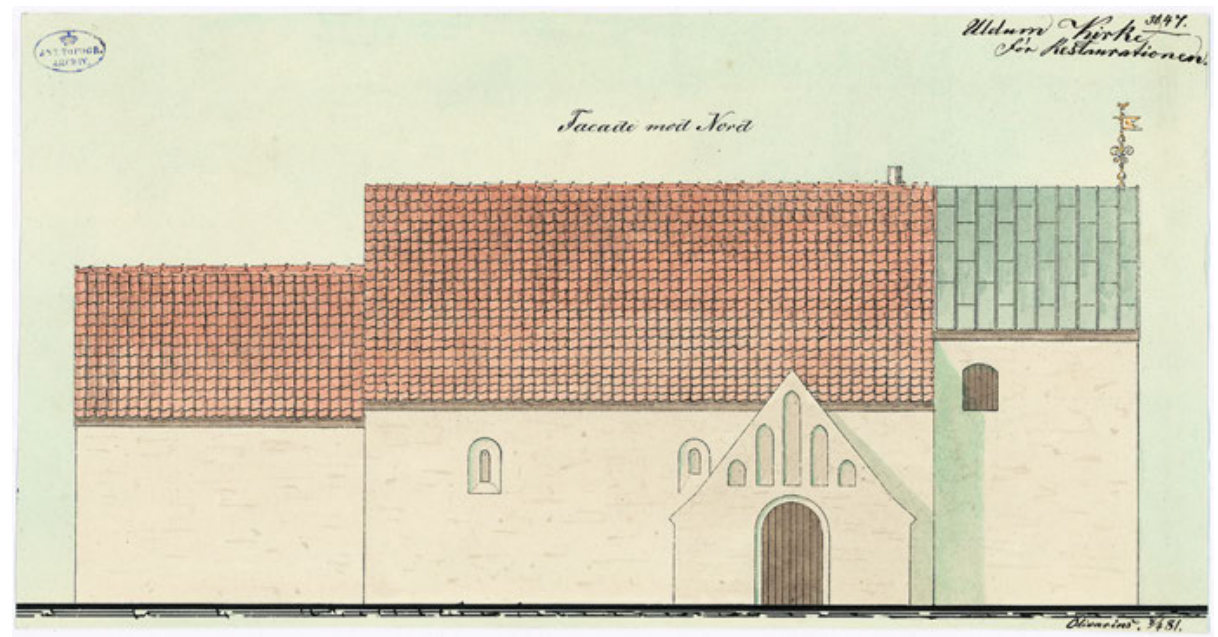

Fig. 13.5: The Old Uldum Church, Jutland, Denmark. Elevation, North, 1:300, 1881. Drawing and measurements by Tage Olivarius. The National Museum of Denmark.

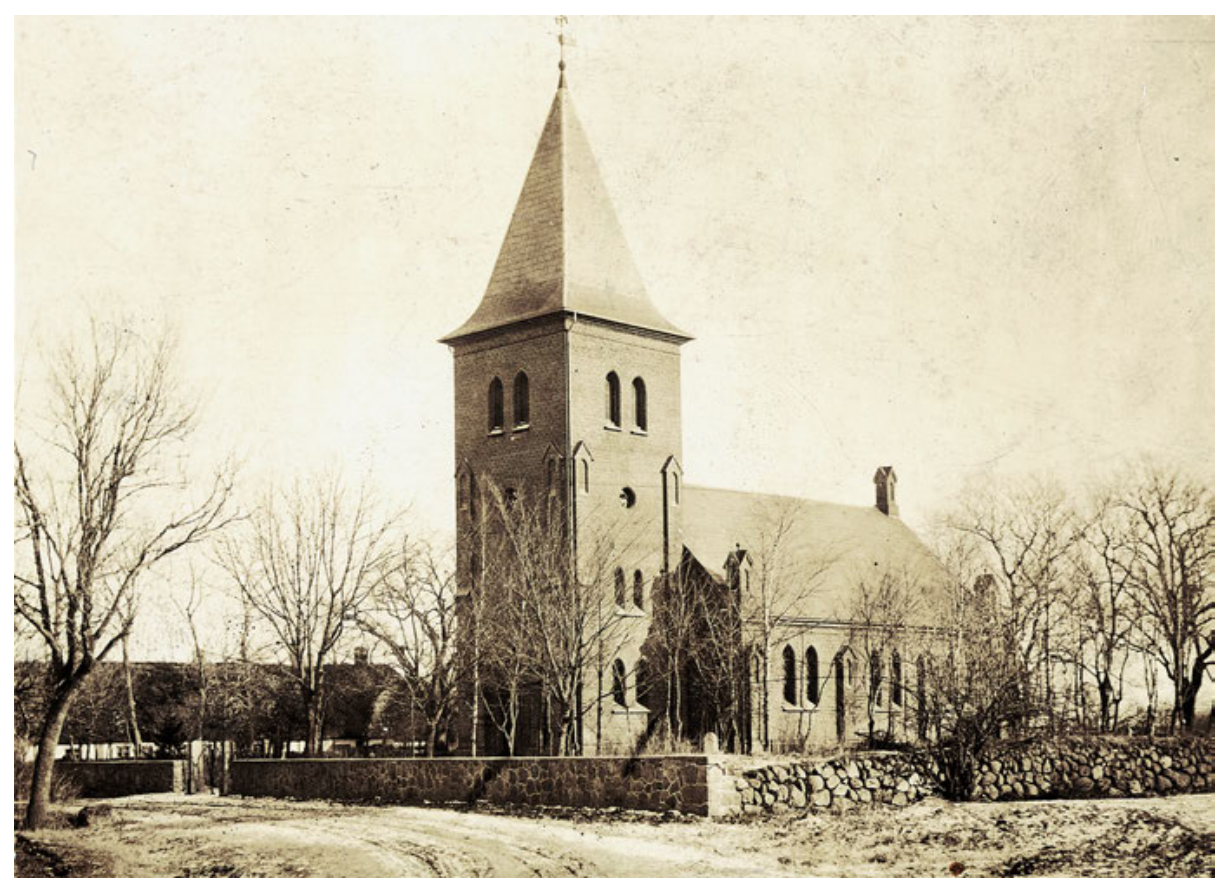

Fig. 13.6: The New Uldum Church, Jutland, Denmark. South-West, c.1900. The National Museum of Denmark. 


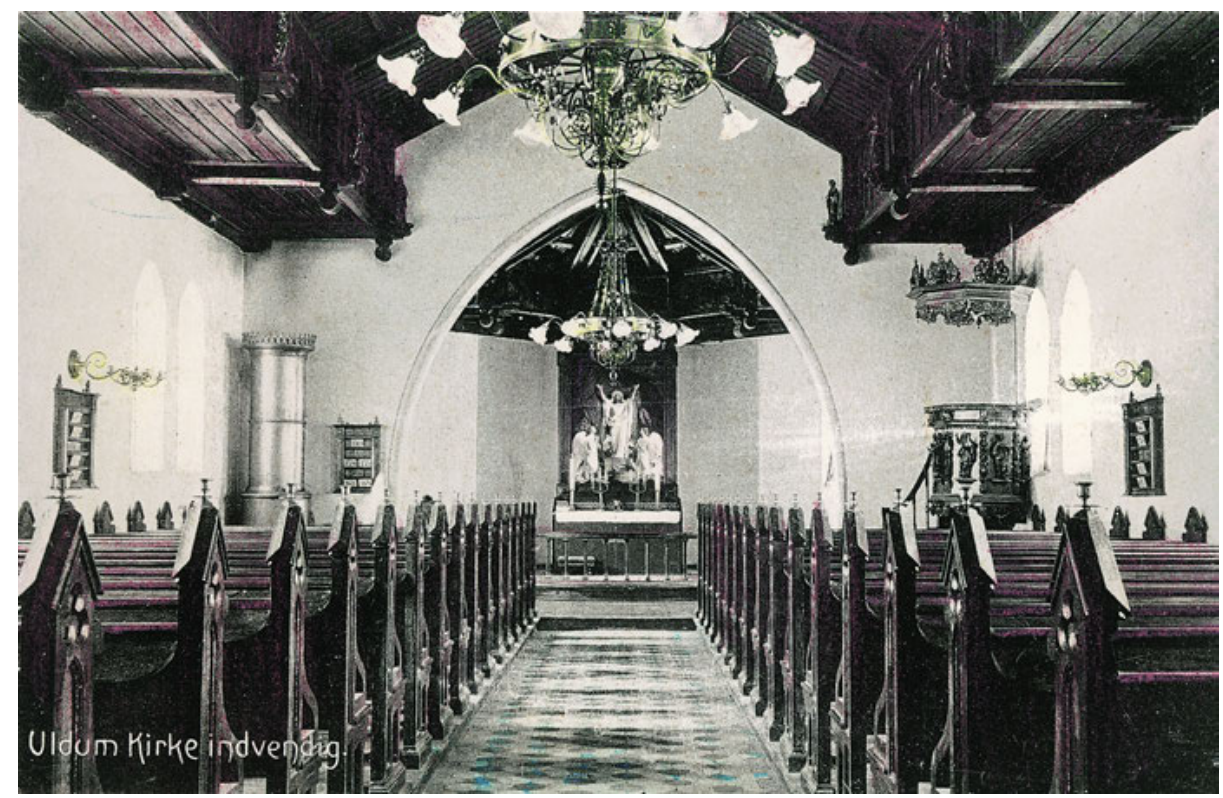

Fig. 13.7: The New Uldum Church, Jutland, Denmark. Interior facing East, c.1900. The National Museum of Denmark.

other chairs were removed from the chancel area along with baptismal fonts. The fonts were moved to the north-east corner of the nave across from the pulpits in the south-east corner. The pews were renewed and enlarged so as to be more comfortable. In 1805 a ban against burials inside the church building was issued. This put a stop to the hanging of wall monuments and the deposition of tomb stones in the floors. The colour suite of the interiors also changed mid-century: from the grey and blue-grey of the late eighteenth century, to the light oakwood imitation of the second quarter of the nineteenth century, to the dark brown oak imitation of the second half. The interior walls were limed; unless remnant murals were deemed suitable in character and thence repainted. New, larger windows were installed and all drapery (curtains, altercloths, etc.) was preferably of crimson velvet. ${ }^{56}$ All in all, the major and general restoration trends did indeed reflect the Act.

In some churches, even more drastic measures were employed. An extreme example is Viborg Cathedral, which was almost entirely torn and rebuilt. The parish church of Fjenneslev, Zealand, on the other hand, was heavily restored. Fjenneslev Church was known to be the seat of the mighty, medieval Hvide dynasty. The church had its vaults with elaborate murals removed in order to re-establish the

56 Jørgensen, Kirkerummets forvandling. 
"original" wooden ceiling, as in the time of Hvide dynasty. ${ }^{57}$ Interestingly, whereas many of the late medieval altar pieces had already been removed from the altars during the late eighteenth and first half of the nineteenth century in line with current trends, a demand for a new type of altarpiece arose in the middle of the century. ${ }^{58}$ Even though, it was by no means a small amount of new altar paintings or completely new altar pieces that were commissioned, most of the more than 2000 parish churches did not get (or could not afford) this type of modernization. In an article from 1867, discussing the consequences of the Act up to this point, Uldall complains that the vast majority of the old altarpieces in the rural parish churches were "of such a nature that they rather gave offence than made for edification, and thus they should be replaced by new ones, which met the intent." 59 He maintains, moreover, that an edifying quality was not only to be expected from an altar painting, it was to be expected from the entirety of the church building; also here Uldall was seemingly calling for the generation of "atmospheres." Already in 1854, the bishop of Zealand, Hans Lassen Martensen had called for the edifying quality of the church space both in terms of the words preached and the art displayed therein: "art may not project any kind of autonomy; it is only to serve as edification."60

\section{Conclusion: "Solemnly Dressed, as is Fitting for the Bride of Christ"}

Even though Uldall, in 1867, is not entirely content with the consequences of the Act, he expresses hope: "One hopes that the Act does not have to enforce, but rather open the eye of every single member of the congregation as to just what it means to have a beautiful and worship-inspiring House of God." ${ }^{61}$ This hope, I would say, lies in the expected effects of the "atmospheric" qualities of original style. That is, that the parishioner would want to return to the church and to the services in order to relive the

57 DKSorø: $324-340$.

58 See Chapter 12 (David Burmeister), 224-43; Jürgensen, "The Properties of Style,” 15; David Burmeister and Martin Wangsgaard Jürgensen, "Omvendelsens billeder. Om Anton Dorphs altertavler," in Nationalmuseets Arbejdsmark (Copenhagen: Nationalmuseet, 2015), 32.

59 "af en saadan Beskaffenhed, at de snarere vække Forargelse, end tjene til Opbyggelse, og at de af den Grund burde ombyttes med nye, der svarede til Hensigten." Uldall, "Om de Danske Landsbykirker og deres Istandsættelse," 139.

60 "Kunsten ikke maa fremtræde med nogensomhelst Selvstændighed, men kun maa underordne sig Opbyggelsens Formaal.” H. Martensen, Om Gudstjenestens Indretning i den Lutherske Kirke. Et Forsøg i den Practiske Theologie (Copenhagen: Bianco Lunos Bogtrykkeri, 1854), 81.

61 My translation. "Som man maa haabe, vil Loven ikke alene behøve at tvinge, men hos mangt et Medlem af Menigheden aabne Øiet for Betydningen af at have et smukt og andagtsvækkende Guds Huus.” Uldall, “Om de Danske Landsbykirker og deres Istandsættelses,” 99. 
transcendental "atmosphere." As such, the "original” style enforced in the Act was a concrete means taken in an effort to rebuild Jerusalem in all of the parishes and in the hearts of the parishioners. Moreover, the Church Inspection Act has yet another but complimentary dimension to it as well. It can, I believe, be understood as a response to the on-going internal ecclesiological strife of the people's church. Along with the transformation of the state church to the people's church, the parish churches were also democratised. This meant, for instance, quite literally that the pews were no longer privately owned and hierarchically arranged according to social strata. It also meant that any single member of the people's church could freely choose to attend any service at any given church. This choice could thus be made, in theory at least, on preference of the teacher; i.e. based on ecclesiological preferences. The standardization of the churches enforced by the Act can in this respect, then, also be understood as a means to amend the heated debates of the period. It testifies to the democratic inclusiveness of the people's church. Building and restoring churches was thus not just an aesthetic play with forms and formats. It was, in fact, a question of the spiritual wellbeing of the nation. It appears that the cluttered church spaces of the first half of the century were believed to have hollowed out the visual rhetoric of Jerusalem; leaving the church building soulless and futile - devoid of "atmosphere.” New hope was introduced with the people's church, which is so clearly echoed the Church Inspection Act. By reviving the buildings' original visual expression, solemnity and edification would again be spurred in the heart of each and every individual of the congregation.

Jerusalem was to be rebuilt in old parish churches by returning them to their “original” style. Ruskin, as a child of the English Evangelical Revival, did not take worship to be conditioned by architecture, whereas the Church Inspection Act, with its embedded theories of style seems to be of a different opinion. The Church Inspection Act explicitly instructs the inspection party of any given church to take care that no shortcomings of the church building or its fittings harm the worship service. Following the Act, explicit visual allusion to Jerusalem merged into an affective notion inextricably linked to style and "atmosphere." It is apparent that the allegory of the church was still very much alive throughout the nineteenth century, but the Bride of Christ only returned in the last half, as so eloquently stated by Høyen:

In our day and age and in a Protestant country, when ecclesiastical art becomes subject to careful consideration, when in the hearts of many there lives a fervent wish for the church to step forward solemnly dressed, as is fitting for the Bride of Christ, it would be only appropriate to clearly state, what is in fact needed in order to embellish the House of God . . . ${ }^{62}$

62 "Naar derfor, i vore Dage og i et protestantisk Land, kirkelig Konst bliver Gjenstand for en nøjere Overvejelse, naar der i Manges Hjærter lever et inderligt ønske om at Kirken maa kunne fremtræde i en Højtidsdragt, saaledes som det sømmer sig for Christi Brud, så vilde det være godt, om man tydeligt gjorde Rede for, hvad der egentlig behøvedes til at smykke Kirken son Guds Hus . . ." Høyen, “Om kirkelig Konst,” 1-30. My translation. 